\title{
The Influence of Environmental Sensitivity, Knowledge and Desire Issues (Intention To Act) with Students Behaviour as State Citizens Towards Environment
}

\author{
Diliana Susilowatia*, Mieke Miarsyah, Diana Vivanti Sigit \\ ${ }^{1}$ Biology Education, Faculty of Mathematics and Natural Sciences, Jakarta State University, Jakarta, 13220, Indonesia \\ dilianasusilowati6@gmail.com; miekemiarsyah@yahoo.com; dianavivanti@yahoo.com \\ *Corresponding Author
}

How to Cite : Susilowatia, D., Miarsyah, M., Sigit, D.,V. (2020). The Influence of Environmental Sensitivity, Knowledge and Desire Issues (Intention To Act) with Students Behaviour as State Citizens Towards Environment.. International Journal for Educational and Vocational Studies, 2 (8), 742-753. DOI:

https://doi.org/10.29103/ijevs.v2i8.2764

\section{ARTICLE HISTORY}

Received: 3 June 2020

Revised: 20 July 2020

Accepted: 27 July 2020

\section{KEYWORDS}

\section{Sensitivity;}

Knowledge of Environmental;

Intention to Act;

Students Behaviour;

Citizens towards Environments

\begin{abstract}
Students' behaviour as citizens towards environment is an act of voluntary and free to conduct activities that benefit the environment. This study aims to analyse the influence environmental sensitivity, knowledge of environmental issues, and intention to act, with students' behaviour as citizens towards the environment. This research was conducted using a quantitative approach and using survey methods, and analysed using path analysis. The number of samples used as respondents was 188 students in grade XI of MIA SMAN 1 Tarumajaya Tambun Utara Kabupaten Bekasi school year of 2019/2020. Based on the results of hypothesis it can be concluded that there is a positive direct influence of environmental sensitivity towards knowledge of environmental issues. There is a direct positive influence of environmental sensitivity on the intention to act. There is a direct positive influence of environmental sensitivity on student behaviour as citizens towards environment. There is a direct positive influence of knowledge of environmental issues on the intention to act. There is a direct positive influence of knowledge of environmental issues on student behaviour as citizens towards environment. There is a direct positive influence of the intention to act on student behaviour as citizens towards environment with large path coefficients. There is an indirect positive influence of environmental sensitivity on the intention to act through the knowledge of environmental issues. There is an indirect positive influence of knowledge of environmental issues on student behaviour as citizens towards environment through the intention to act. There is an indirect positive influence of environmental sensitivity on student behaviour as citizens towards environment through the knowledge of environmental issues and the intention to act.
\end{abstract}

This is an open access article under the CC-BY-SA license.

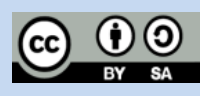

\section{INTRODUCTION}

Environmental damage is inevitable, various policies and regulations continue to be promoted but environmental damage from time to time is quite large and broad impact. This problem needs to be studied more deeply because of the importance of health environment and natural function balance. Environmental problems in various cases both globally or nationally are largely based on human attitudes and behaviour. Cases of pollution and environmental damage sourced from irresponsible, indifferent and selfishness of human behaviour (Widiyanto et al, 2015).

This ignorance can be seen by the large number of students who do not have any awareness to maintain cleanliness of the classroom and school environment (Pratama, 2013). The attitude and behavior in interacting with this environment are the results of individual decisions, how these individuals treat the environments well (Iskandar, 2009).

Citizenship behaviour can be defined as voluntary activities carried out by a person who is not expected rewards that may not be appreciated, but can contribute in improving the quality of the environment (Colquit, Lepine and Wesson, 2011). According to Hungerford and Volk (2013), a person will behave as a citizen towards the environment is influenced by several variables. These variables include entry-level variables, ownership variables, and empowerment variables. Entry-level variables such as environmental sensitivity, ownership variables for example knowledge of environmental issues, and as empowerment variables are intentions to act. 
Priadi et all (2018) examined about the influence of environmental sensitivity, environmental knowledge, personal investment in environmental issues, with the locus of control of students as citizens of their environment. These five variables have a significant relationship. Citizenship behaviour will be formed if knowledge of environmental issues and the level of sensitivity of the environment are both high.

The environment has a role as one of the very important variables in a person to behave on the environment. Chawla (1998) in Pan (2018) defined environmental sensitivity as a tendency to study about environmental problems and issues, feeling concerned for it, and acting to preserve it, based on formative experience. Peterson (1982) in Cheng and Wu (2014) reported about claiming environmental sensitivity that a person with a higher level of knowledge of environmental issues will feel more respectful, caring, and show empathy for the environment. To minimize the problem, the knowledge of environmental issues needs to be developed and improved because a person is considered to be able to strengthen their sensitivity to the environment by how improved the knowledge of environmental issues is.

According to Cheng et all (2013), knowledge of environmental issues is a set of ecological knowledge possessed by individuals regarding the environment. Meanwhile according to Huang and Shih (2009), knowledge of environmental issues is related to understanding and caring about the natural environment both in preserving and taking advantages and its effects that are created, and will encourage a stronger individual responsibility to preserve the environment. Meanwhile according to Townsend (2000), knowledge of environmental issues and environmental observer help increasing environmental sensitivity and will be demonstrated by citizenship behaviour towards impacted environment on reducing the damage to the surrounding. The knowledge of environmental issues is expected to be able to change the perceptions, attitudes, and behaviour of people who care about the environment in a sustainable way, not only for now but also for the benefit of future generations. According to Azjen et all (2011), it cannot be denied that schools play an important role in providing knowledge of environmental issues. The school provides knowledge about this environmental issue directing and producing students who are able to be sensitive to environmental issues, willing to take action (intention to act) and produce good citizenship behaviour towards the environment.

Kanchanapibul, Lacka, Wang, and Chan (2014) found that the younger generations as consumers by owning knowledge of environmental issues will have a stronger will to act environmentally responsible. According to Wang, Liu, and Qi (2014) knowledge of environmental issues positively affect one's will to act and this willingness to act positively affects an environmentally responsible behaviour. Sensitivity, knowledge of environmental issues, and willingness to act will contribute student to behave as citizens of the environment. Therefore, this study will examine the influence of sensitivity environment, knowledge of environmental issues and the intention to act with student behaviour as citizens of the environment. The results of the study are expected to provide inputting to policy makers for the success of the Environmental Care and Cultured School program.

\section{MATERIALS AND METHODS}

This research used a quasi-experimental method to determine the effect of learning strategies and motivation levels on student learning outcomes s. The learning strategies in this study were divided into two, namely the JiRQA learning strategy for the experimental class and the RQA learning strategy for the control class. While the motivation in this research includes high and low motivation. So the design used is a $2 \times 2$ factorial experiment design.

This research was conducted at SMA Negeri 1 Tarumajaya and SMA Negeri 1 Tambun Utara, Bekasi, Jawa Barat, in 2020. The method used is descriptive research with a quantitative approach. Endogenous variables in this study is the behaviour of students and citizens of the environment and the exogenous variables in this study are knowledge of environmental issues and environmental sensitivity. The population in this study is all students in SMA grade X IPA in Kabupaten Bekasi, Provinsi Jawa Barat, the technique used is multi-stage sampling so there would be 188 samples from 387 respondents. The instrument used was in the form of questionnaire that was validated its validity.

\section{RESULTS AND DISCUSSIONS}

The results of the analysis are the correlation data and path analysis of the research path.

a. Correlation analysis based on correlation diagram

b. The Direct Influence of Environmental Sensitivity $\left(\mathrm{X}_{1}\right)$ and Knowledge of Environmental Issues $\left(\mathrm{X}_{2}\right)$. 


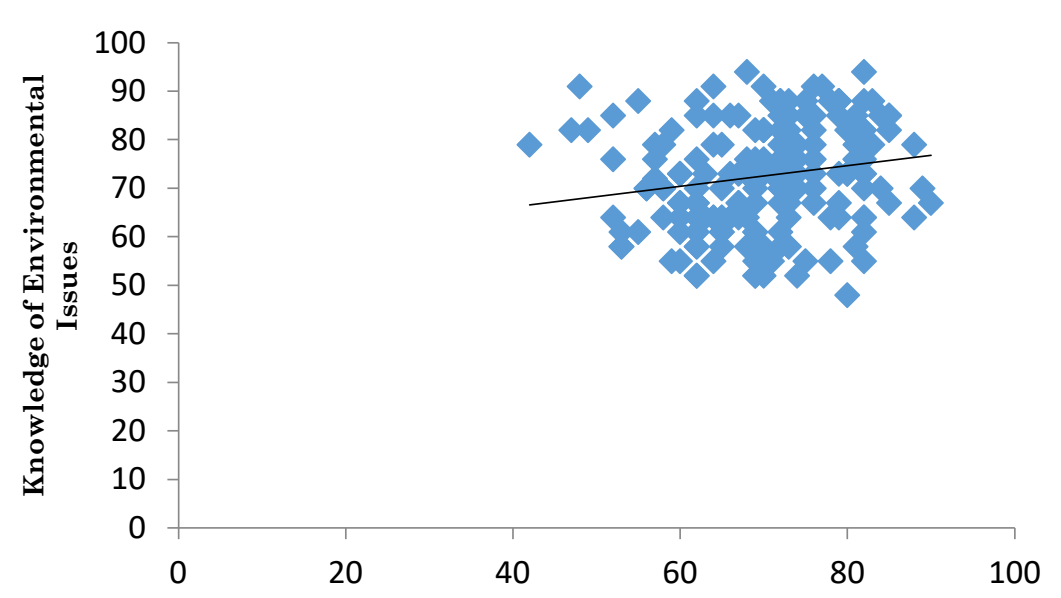

Figure 1. Chart of Equation $\mathrm{X}_{2}=57.627+0.213 \mathrm{X}_{1}$

1. Direct Influence of Environmental Sensitivity $\left(\mathrm{X}_{1}\right)$ and the Intention to Act $\left(\mathrm{X}_{3}\right)$

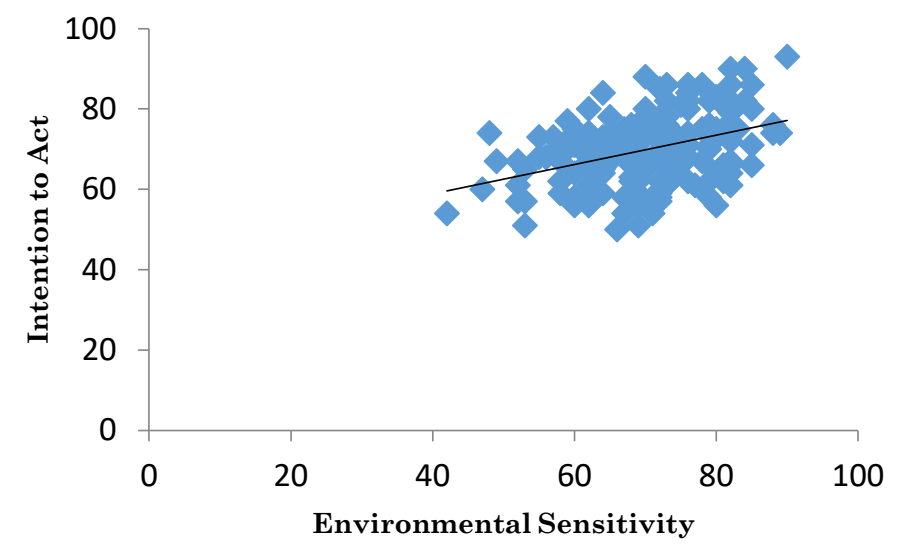

Figure 2. Chart of Equation $\mathrm{X}_{3}=44.290+0.366 \mathrm{X}_{1}$

2. The Direct Influence of Environmental Sensitivity $\left(\mathrm{X}_{1}\right)$ and Student Behaviour as Citizens of the Environment $\left(\mathrm{X}_{4}\right)$

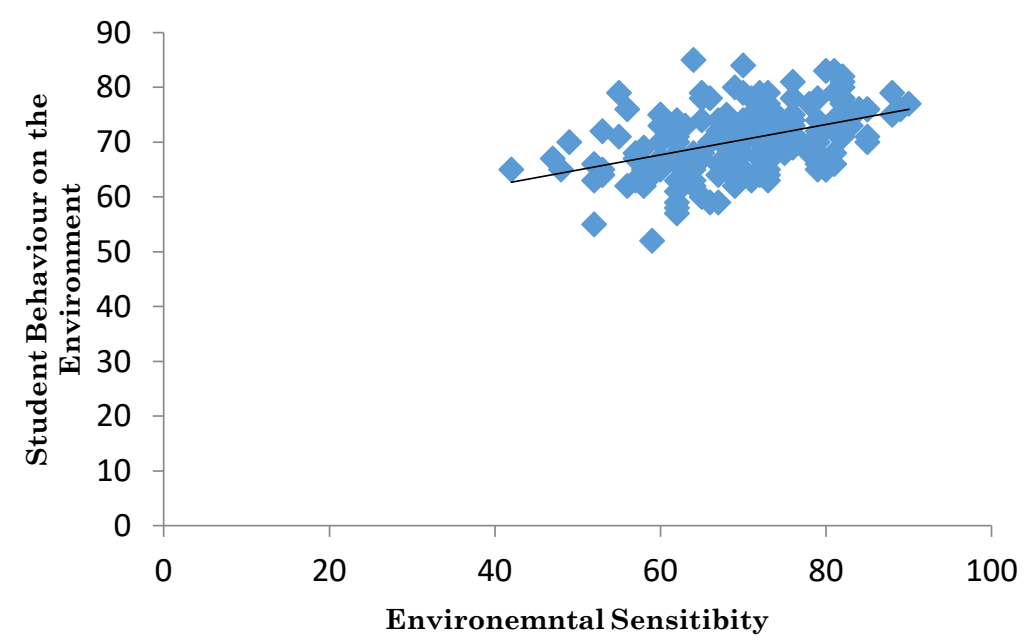


3. The Direct Influence of Knowledge of Environmental Issues $\left(\mathrm{X}_{2}\right)$ and the Intention to Act $\left(\mathrm{X}_{3}\right)$

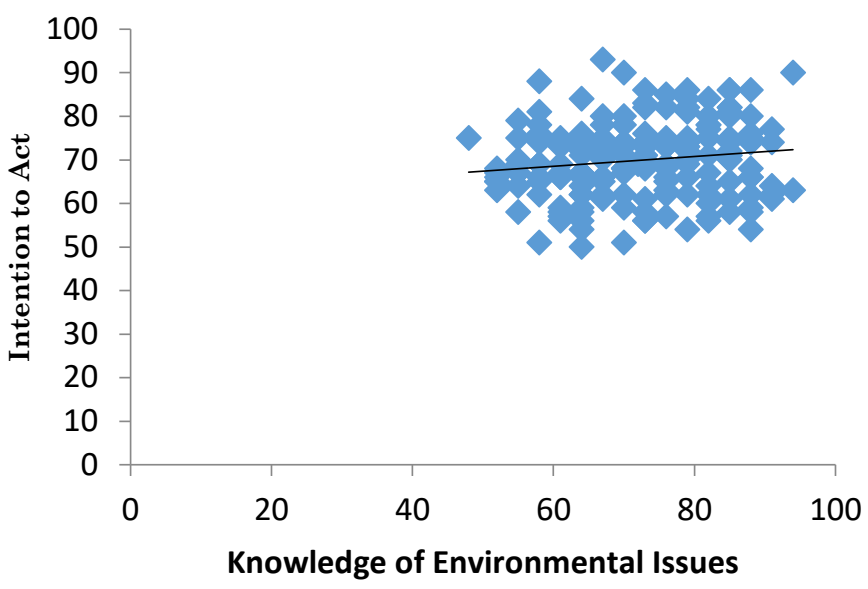

4. The Direct Influence of Knowledge of Environmental Issues $\left(\mathrm{X}_{2}\right)$ and Student Behaviour as Citizens $\left(\mathrm{X}_{4}\right)$

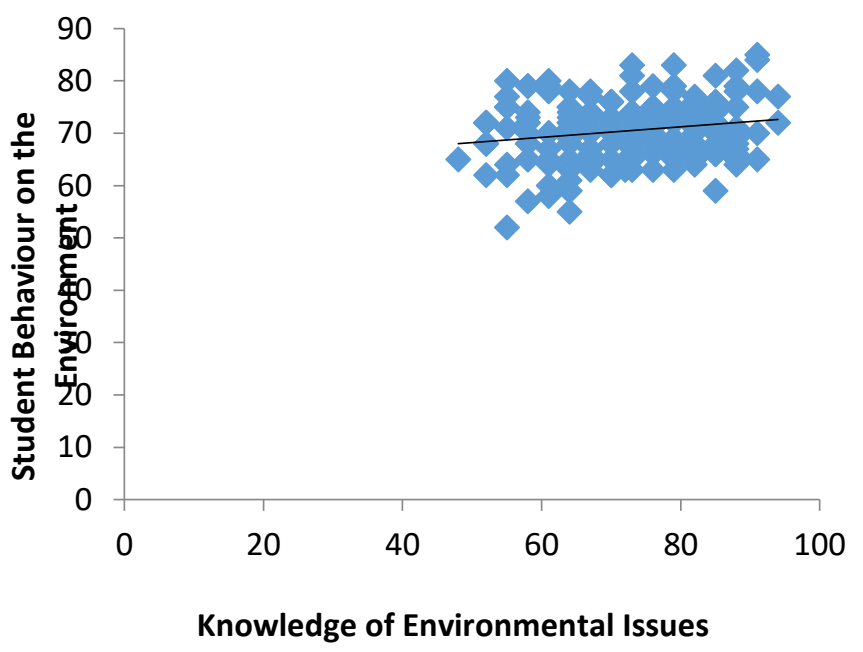

5. The Direct Influence of Intention to Act $\left(\mathrm{X}_{3}\right)$ and Student Behaviour as Citizens of the Environment $\left(\mathrm{X}_{4}\right)$

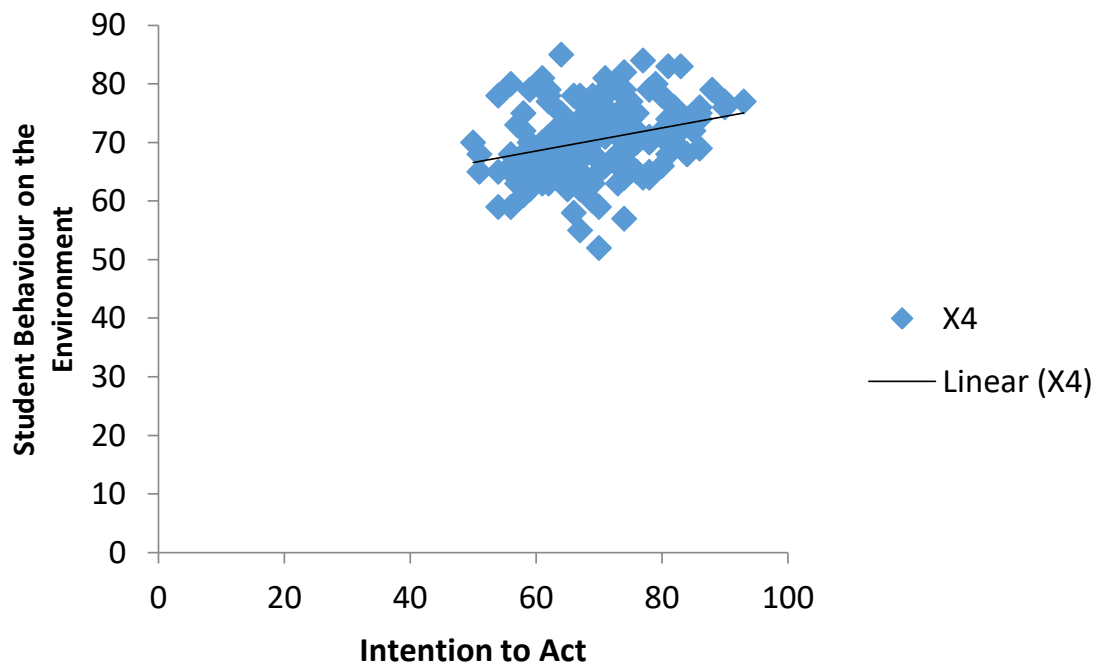




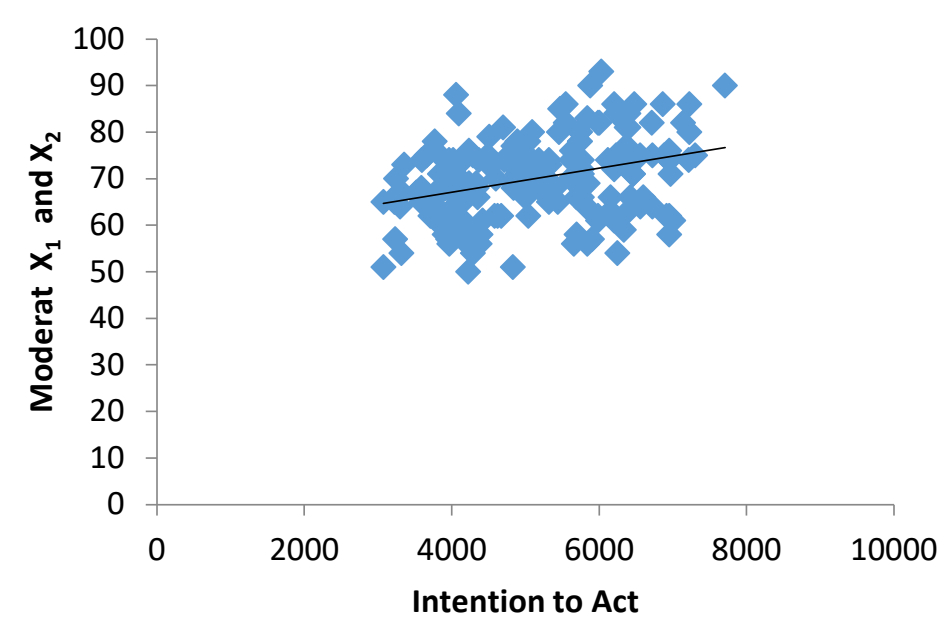

6. he Indirect Influence of Environmental Sensitivity $\left(\mathrm{X}_{1}\right)$ and the Intention to Act $\left(\mathrm{X}_{3}\right)$ through the

7. The Indirect Influence of the Knowledge of Knowledge of Environmental Issues $\left(\mathrm{X}_{2}\right)$ Environmental Issues $\left(\mathrm{X}_{2}\right)$ and Student Behaviour as Citizens of the

8. Environment $\left(\mathrm{X}_{4}\right)$ through the Intention to Act $\left(\mathrm{X}_{3}\right)$
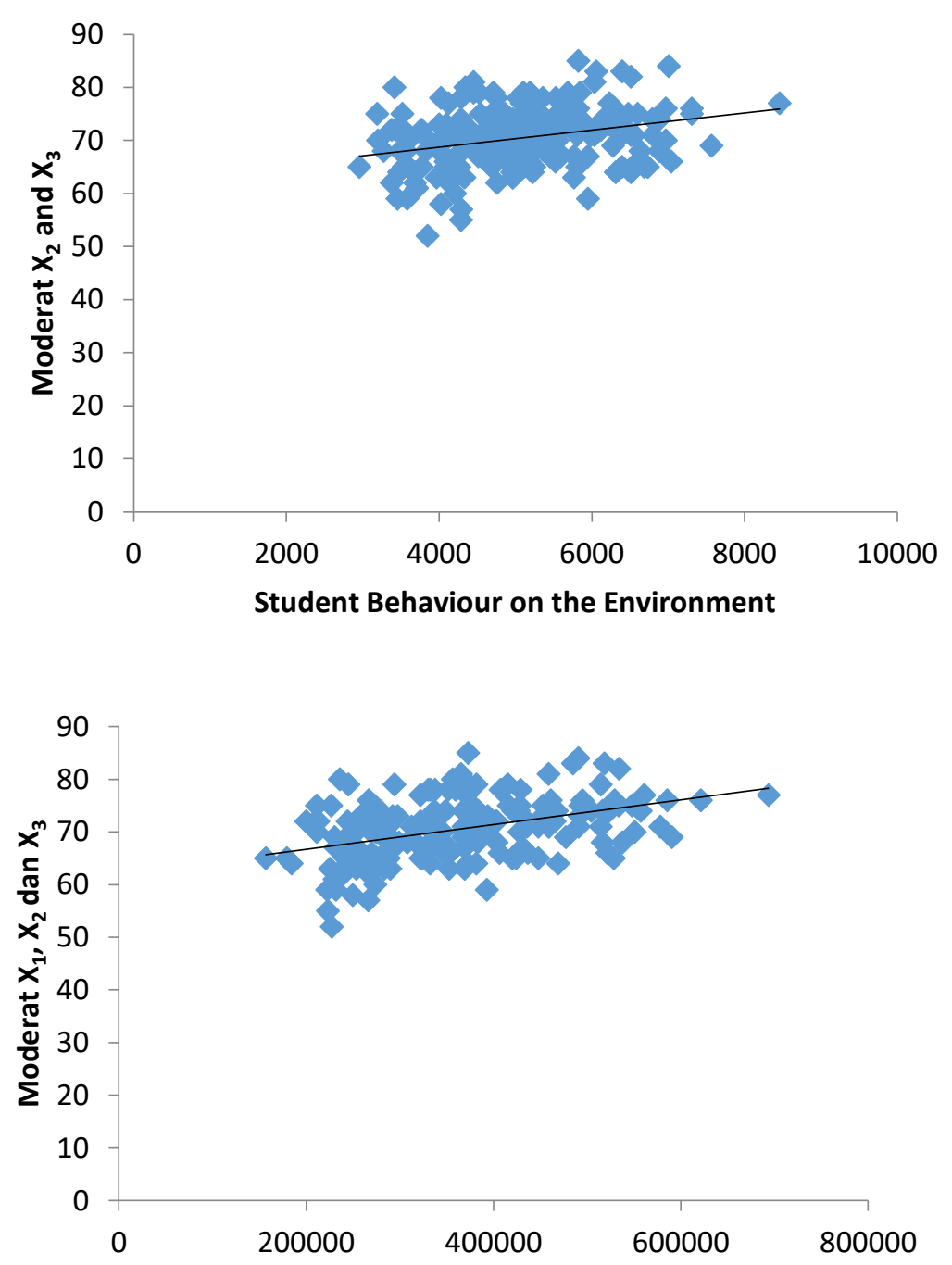
9. The Indirect Influence of Environmental Sensitivity $\left(\mathrm{X}_{1}\right)$ and Student Behaviour as Citizens of the Environment $\left(\mathrm{X}_{4}\right)$ through the Knowledge of Environmental Issues $\left(\mathrm{X}_{2}\right)$ and the Intention to Act $\left(\mathrm{X}_{3}\right)$

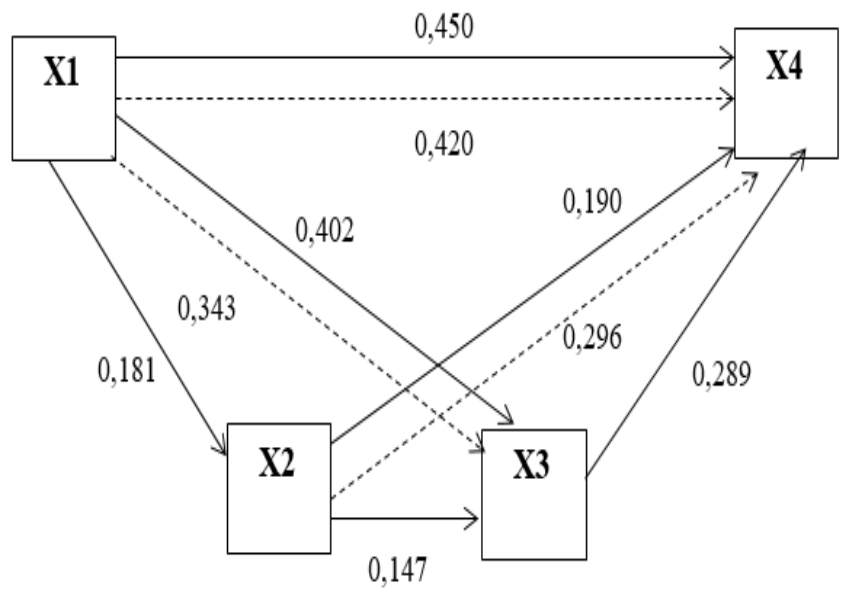

Note:

X4 : Student behaviour on the Environment

$\mathrm{X} 1$ : Environmental Sensitivity

X2 : Knowledge of Environmental Issues

X3 : Intention to Act

$\longrightarrow$ : Direct Influences

$-\rightarrow$ : Indirect Influences

The Environmental Sensitivity $\left(\mathrm{X}_{1}\right)$ and Knowledge of Environmental Issues $\left(\mathrm{X}_{2}\right)$

The first hypothesis test results of the study that obtained a coefficient of degermation of 0.181 by using the Person Test Product Moment shows that there is a direct influence between environmental sensitivity and knowledge of environmental issues. This positive relationship shows that environmental sensitivity has a contribution to the intention to act by $18.1 \%$. It means that by $18.1 \%$ of the variable of knowledge on environmental issues $\left(\mathrm{X}_{2}\right)$ can be explained by the variable of environmental sensitivity $\left(\mathrm{X}_{1}\right)$. While the rest is influenced by other variables outside the studied model. Sensitivity to the surrounding environment makes a student find out what things can cause environmental damage. This sensitivity factor makes a power in one's heart to care more and learn the environment. A student who has a high level of sensitivity also know the latest events about environmental destruction both on land and in water. The results of this study support the results of previous studies which also concluded that sensitivity significantly influences a person in mastering knowledge about their environmental issues (Chalwa, 2016). In line with that, the studies of Pan et al (2018), Chalwa (2016), Hsu and Roth in Hsu (2010), and Priadi et al (2018), state that increasing the sensitivity of a person's environment can also increase a person's behaviour as citizens of the environment. This can prove the theory written by Hungerford and Volk (2013).

The Environmental Sensitivity $\left(\mathrm{X}_{1}\right)$ and the Intention to Act $\left(\mathrm{X}_{3}\right)$

The second hypothesis test results of the study that obtained a coefficient of determination of 0.402 by using the Person Test Product Moment shows that there is a direct influence between environmental sensitivity and students' intention to act towards the environment. This positive relationship shows that environmental sensitivity affects intention to act by $40.2 \%$. That means that by $40.2 \%$ of the variable of intention to act $\left(\mathrm{X}_{3}\right)$ can be influenced by the variable of environmental sensitivity $\left(\mathrm{X}_{1}\right)$. While the rest is influenced by other variables outside the studied model. Based on the results of the path analysis of $\mathrm{X}_{1}$ to $\mathrm{X}_{3}$, obtained results Phi21, which means there is a direct influence between environmental sensitivity $\left(\mathrm{X}_{1}\right)$ to intention to act $\left(\mathrm{X}_{3}\right)$. This shows that environmental sensitivity can significantly influence the intention to act. This can be concluded that the increased environmental sensitivity will influence a significant increase in students' intention to act. The higher the environmental sensitivity will affect the increasing students' intention to act. 
Environmental sensitivity owned by student gives positive thoughts and eagers them to act on their environment. This supports the research that has been done by Hungerford and Volk (2013) that explained that environmental sensitivity is a perspective of empathy for the environment, which has been considered as one of the variables that contributes with the intention to act and behaving pro-environment. Environmental sensitivity is a prerequisite or at least the variables that will increase one in making decision and intention to act towards the environment. In the theory written by Hungerford and Volk (2013), there was a Behaviour Flow Chart model of "Environmental Citizenship Behaviour" which places environmental sensitivity on major variables before the intention to act, which means environmental sensitivity influences a person's intention to act on the environment. The results of this study are eventually able to support the statement and it can be concluded that environmental sensitivity has a direct influence on the students' intention to act on the environment.

The Environmental Sensitivity $\left(\mathrm{X}_{1}\right)$ and Student Behaviour as Citizens of the Environment $\left(\mathrm{X}_{4}\right)$

The third hypothesis test results of the study that obtained a coefficient of determination of 0.450 by using the Person Test Product Moment shows that there is direct influence between environmental sensitivity and student behaviour as citizens of the environment. This positive relationship shows that environmental sensitivity has the contribution of student behaviour as citizens to the environment by $45 \%$ (Appendix 10). It means that by $45 \%$ of the variables of student behaviour as citizens of the environment $\left(\mathrm{X}_{4}\right)$ can be explained by the variable of environmental sensitivity $\left(\mathrm{X}_{1}\right)$. While the rest is influenced by other variables outside the studied model. Based on the calculation results of path analysis of $\mathrm{X}_{2}$ to $\mathrm{X}_{3}$, obtained Phi21 results of 0.450 , this shows that knowledge of environmental issues can significantly influence the intention to act. Thus, it can be concluded that increasing knowledge of environmental issues will affect the increase of intention to act significantly. The higher the knowledge of environmental issues, the higher the intention to act. Knowledge of environmental issues that a student has affects their intention to act in the environment. Environmental sensitivity is the main variable that contributes to the creation of a person's citizenship behaviour on the environment. Environmental sensitivity, as a point of view of empathy for the environment, is very influential a person in treating the environment. Individuals who are sensitive to the environment have an appreciation and great concern for the natural environment. This is proved from the results of the research that shows students who have a high score on environmental sensitivity will also get a high score on students' citizenship behaviour to the environment. The results of the study support the research conducted by Chawla (1998) in Pan (2018) that explained that environmental sensitivity is as a point of view of empathy for the environment and classify it as an important variable of environmental awareness as well as a reason for behaving citizens on the environment. In line with this opinion, Cheng and Wu (2014) and Turner (1980) in Cheng and $\mathrm{Wu}$ (2014) have the same opinion that environmental sensitivity is one of the variables that contribute in creating citizenship behaviour towards the environment, caring and maintaining the environment. The theory in Hungerford and Volk (2013) shows that environmental sensitivity is an empathetic perspective on the environment, which has been considered as one of the variables that contribute in creating citizenship behaviour towards the environment. Environmental sensitivity is positioned as an entry variable that can shape a person's behaviour as a citizen on the environment. In line with this, the results of this study are able to prove the theory of Hungerford and Volk (2013) that there is a significant influence between the environmental sensitivity a student has and a student's behaviour as citizen of the environment. Pan, Chou, Marisson, Hung and Lin (2018) in The Environmental Behavioural Intentions of University Tourism Students also support this opinion that increased environmental sensitivity will improve the behaviour of students as citizens of their environment.

The Direct Influence of Knowledge of Environmental Issues $\left(\mathrm{X}_{2}\right)$ and the Intention to $\operatorname{Act}\left(\mathrm{X}_{3}\right)$

The fourth hypothesis test results the obtained by coefficient of determination of 0.147 by using the Person Test Product Moment shows that there is a direct 
influence between knowledge of environmental issues with the intention to act. This positive relationship shows that knowledge of environmental issues has a contribution in student behaviour as citizens of the environment by $14.7 \%$ (Appendix 10). It means that by $114.7 \%$ of the variable of knowledge of environmental issues $\left(\mathrm{X}_{2}\right)$ can be explained by the variable of intention to act $\left(\mathrm{X}_{3}\right)$. While the rest is influenced by other variables outside the studied model. Based on the calculation results of path analysis of $\mathrm{X}_{2}$ to $\mathrm{X}_{4}$, obtained Phi21 results of 0.450 , this shows that knowledge of environmental issues can influence significantly towards the behaviour of students as citizens of the environment. This can be concluded that increased knowledge of environmental issues will affect the improvement of student behavior as citizens significantly to the environment. The higher the knowledge of environmental issues, the more influential on increasing student behaviour as citizens of the environment. The knowledge of environmental issues a student influences the behaviour of students as citizens of their environment. The results of testing the variable on the fourth hypothesis, the knowledge of environmental issues directly influences the intention to act. Knowledge shapes students' concepts and mindsets for a better way when they act. Students who have knowledge of the environmental issues can increase the intention to act so that will arise a sense of caring for the environment. The results are able to prove the opinion of Mundiah (2013) which states that student's knowledge is one indicator that indicates the tendency of students to act or not act on the environment. The knowledge of environmental issues the students have implicate in caring and tolerance for the natural environment. This study supports the research conducted by Hine et al (1995) in Bamberg and Mo"ser (2006) who state that knowledge of environmental issues have an positive influence on the intention to act. In line with this opinion, Hsu (2010) also believes that increasing knowledge of environmental issues in a person can significantly influence the intention to act.

The Direct Influence of Knowledge of Environmental Issues $\left(\mathrm{X}_{2}\right)$ and Student Behaviour as Citizens $\left(\mathrm{X}_{4}\right)$

The fifth hypothesis test results that obtained by the coefficient of determination of 0.190 by using the Person
Test Product Moment shows that there is a direct influence between knowledge of environmental issues with student behaviour as citizens of the environment. This positive relationship shows that knowledge of environmental issues has contributed by $19 \%$ of student behaviour as citizens to the environment. That means that by $19 \%$ of the variable of knowledge of environmental issues $\left(\mathrm{X}_{2}\right)$ can be explained by the variable of behaviour of students as citizens on the environment $\left(\mathrm{X}_{4}\right)$. While the rest is influenced by other variables outside the studied model. Based on the results calculation of path analysis of $\mathrm{X}_{2}$ to $\mathrm{X}_{4}$, obtained Phi21 results of 0.450 , this shows that knowledge of environmental issues can significantly influence student behaviour as citizens on the environment. It can be concluded that increasing knowledge of environmental issues will influence significantly in improving student behaviour as citizens of the environment. The higher the knowledge of environmental issues will affect the increasing behaviour of students as citizens of the environment. Knowledge of environmental issues that a student has affects the behaviour of students as citizens of its environment. Knowledge of environmental issues is a major variable that shapes student behaviour as citizens towards the environment. The higher one's knowledge will encourage a person to behave well on his environment as a citizen who can protect the environment around them. Knowledge of environmental issues will provide quite extensive knowledge about an event and its causes mainly from destructive behaviour. After having the knowledge of current environmental issues, it will affect for a person to give reasons for actions taken to behave in accordance with rules as good citizens on the environment. This is proved from the results of the research conducted, a student who gets a high score knowledge of environmental issues will also get high scores on student behaviour as citizens on the environment. The results of this study prove the opinions of Pan, Chou, Marisson, Hung and Lin (2018) in The Environmental Behavioural Intentions of University Tourism Students that increasing environmental knowledge in students at the school will improve the behaviour of students as citizens of their environment. In line with the results of Pan et al (2018), Hsu (2010) also concluded that increasing knowledge about the environment in students significantly 
influencing citizenship behaviour towards the environment.

The Direct Influence of Intention to Act $\left(\mathrm{X}_{3}\right)$ and Student Behaviour as Citizens of the Environment $\left(\mathrm{X}_{4}\right)$

The sixth hypothesis test results of the study that obtained a coefficient of determination of 0.289 using the Person Test Product Moment (Appendix 10) shows that there is a direct influence between the intention to act with behaviour students as citizens of the environment. This positive relationship shows that the intention to act has the contribution of student behaviour as citizens to the environment by $28.9 \%$ (Appendix 10). It means that by $28.9 \%$ of the variable of the intention to act $\left(\mathrm{X}_{3}\right)$ can be explained by the variable of behaviour of students as citizens of the environment $\left(\mathrm{X}_{4}\right)$. While the rest is influenced by other variables outside the studied model. Based on the calculation results of path analysis of $\mathrm{X}_{3}$ to $\mathrm{X}_{4}$, obtained Phi21 results of 0.289 , this shows that the intention to act can significantly influence the behaviour of students as citizens of the environment. This can be concluded that increased intention to act will significantly affect the increasing student behaviour as citizens to the environment. The higher the intention to act it will affect increasing student behaviour as citizens of the environment. Based on the results of the sixth hypothesis testing, it shows that the intention to act a student can be influential directly towards the behaviour of students as citizens of their environment. When student's intention to act high, it will affect the behaviour of students as citizens of their environment. Student who has a strong intention to act will have a reason to behave and to save the environment. This is proved from the results of the analysis obtained that students who have high scores on the intention to act also get a high score on student behaviour as citizens of their environment. The sixth hypothesis testing results show that a student's intention to act can directly influence the behaviour of students as citizens of its environment. When a student has a high intention to act, it will affect student behaviour as citizens of their environment. Students who have a strong intention to act will have a reason to behave and to save the environment. This is proved from the analysis results obtained by students who have high score on the intention to act also get a high score on the behaviour of students as citizens of its environment. The results of this data analysis support the research of His and Roth in Hsu (2010) which states that there is a significant influence between a person's intention to behave with the behaviour of students as citizens of its environment. It also supports the opinion of Priadi et al (2018) about citizenship behaviour that will be formed if the level of knowledge of environmental issue is also high.

The Indirect Influence of Environmental Sensitivity $\left(\mathrm{X}_{1}\right)$ and the Intention to Act (X3) through the Knowledge of Environmental Issues $\left(\mathrm{X}_{2}\right)$

The seventh hypothesis test results that obtained by the coefficient of determination of 0.343 by using the Person Test Product Moment shows that there is an indirect influence between environmental sensitivity and the intention to act through the knowledge of environmental issues. This positive relationship shows that environmental sensitivity has a contribution of intention to act through knowledge of environmental issues by $34.3 \%$. It means that by $34.3 \%$ of the variable of environmental sensitivity $\left(\mathrm{X}_{1}\right)$ can be explained by the variable of intention to act $\left(\mathrm{X}_{2}\right)$ accompanied by knowledge of environmental issues $\left(\mathrm{X}_{2}\right)$. While the rest is influenced by other variables outside the studied model. Based on the calculation results path analysis of $\mathrm{X}_{1}$ to $\mathrm{X}_{3}$, obtained Phi21 results of 0.343 , this can be concluded that increased environmental sensitivity will indirectly affect significantly the increase of intention to act through knowledge of environmental issues. The higher the environmental sensitivity, the more affect indirectly on the increasing intention to act accompanied by increased knowledge of environmental issues. The environmental sensitivity of a student affects indirectly the intention to act accompanied knowledge of environmental issues. Based on the results of data analysis, it can be concluded that environmental sensitivity has a significant influence with the intention to act followed by knowledge of environmental issues. Environmental sensitivity followed by a high level of knowledge of environmental issues is able to influence indirectly the intention to act students who will arise when interacting in their environment. This can also be said that the intention of act expressed by a student begins with a sense of environmental sensitivity 
to the environment and based on the influence of the level of knowledge of environmental issues provides direction for choosing what actions will be taken by the students. The testing on the seventh hypothesis the basic behaviour of the action that will be taken, the intention to act students from student sensitivity variables and mastery of knowledge of environmental issues. This is done to find out deviant behaviour and unwise actions taken on the environment. These behaviours which are later expected to be changed early, by increasing environmental sensitivity and knowledge of the environmental issues. This research is important because it is able to detect a person's expressions or actions. This research supports the opinion of Hungerford and Volk (2013) about environmental sensitivity that is a prerequisite, or at least variables that will improve one in making decision and intention to act on the environment. Another proof of opinion from Chawla (1998) in Pan (2018) which concludes that environmental sensitivity as a tendency to study environmental problems, will later feel concerned for it, and willing to act to preserve it.

The Indirect Influence of the Knowledge of Environmental Issues $\left(\mathrm{X}_{2}\right)$ and Student Behaviour as Citizens of the Environment $\left(\mathrm{X}_{4}\right)$ through the Intention to Act $\left(\mathrm{X}_{3}\right)$

The eighth hypothesis test results that obtained by the coefficient of determination of 0.420 by using the Person Test Product Moment (Appendix 10) shows that there is an indirect influence between knowledge of environmental issue with student behaviour as citizens of the environment through the intention to act. This positive relationship shows that knowledge of environmental issues has contributed to student behaviour as citizens towards environment through the intention to act by $42 \%$ (Appendix 10). It means that by $42 \%$ of the variable of knowledge of environmental issues $\left(\mathrm{X}_{2}\right)$ can be explained by the variable of behaviour of students as citizens of the environment $\left(\mathrm{X}_{4}\right)$ through intention to act $\left(\mathrm{X}_{3}\right)$, while the rest is influenced by other variables outside studied model. Based on the results calculation of path analysis of $\mathrm{X}_{2}$ to $\mathrm{X}_{4}$ through $\mathrm{X}_{3}$, obtained Phi21 results of 0.420 , this shows that knowledge of environmental issues can indirectly influence significantly on student behaviour as citizens of the environment accompanied by the intention to act. This can be concluded that the increase knowledge of environmental issues will indirectly influence the improvement of student behaviour as citizens to the environment accompanied by a significantly increased intention to act. The higher the knowledge of environmental issues will have an indirect influence on increasing student behaviour as citizens towards the environment is accompanied by an increased intention to act. Knowledge of environmental issues that a student has indirectly affects the behaviour of students as citizens of their environment accompanied by an intention to act.

The proof of the eighth hypothesis shows that knowledge of environmental issues is able to indirectly influence the student's behaviour as citizens through the intention to act environmentally. Students who have high score on knowledge of environmental issues accompanied by a strong intention to act can directly increase student's behaviour as citizens of the environment. However, when they stand alone, each of these variables is able to directly influence the student's behaviour as citizens of the environment. This is more likely to be influenced by the results of conducted research, the accuracy of the items used as indicators and assessment of knowledge of environmental issues and an intention to act in accordance with the circumstances of the studied sample. The other possibility is students who have high environmental sensitivity and an intention to act responsible for the environment. This research proves that the results from Hsu and Roth's research in Hsu (2010) which states there is a significant relationship between environmental sensitivity, knowledge of environmental issues with intention to act. In line with the opinion of Hsu (2010), the opinion of Yusof, Singh and Rozak (2013) also explains that a person who has knowledge of environmental issues, both related to what and how the role of the environment is in human life, then a person will seek his actions consciously eager to act in order the environment is not damaged which results in a person's behaviour as a citizen of his environment.

The Indirect Influence of Environmental Sensitivity $\left(\mathrm{X}_{1}\right)$ and the Intention to Act $\left(\mathrm{X}_{3}\right)$ through the Knowledge of Environmental Issues $\left(\mathrm{X}_{2}\right)$ 
The ninth hypothesis test results obtained by the coefficient of determination of 0.420 by using the test Person Product Moment shows that there is an indirect influence between environmental sensitivity and student's behaviour as citizens of the environment through knowledge of environmental issues and the intention to act. This positive relationship shows that environmental sensitivity has contributed to student's behaviour as citizens to the environment through knowledge of environmental issues and the intention to act by $42 \%$. That means that by $42 \%$ of the variable of environmental sensitivity $\left(\mathrm{X}_{1}\right)$ can be explained by the variable of behaviour of students as citizens towards environment $\left(\mathrm{X}_{4}\right)$ through the variable of knowledge of environmental issues $\left(\mathrm{X}_{2}\right)$ and the variable of intention to act $\left(\mathrm{X}_{3}\right)$, while the rest is influenced by other variables outside the studied model. Based on the calculation results of path analysis of $\mathrm{X}_{1}$ to $\mathrm{X}_{4}$, Phi21 results obtained by 0.420 with $t_{\text {count }}=6.310>t_{\text {table }}=1.653$, which means there is a direct influence between environmental sensitivity $\left(\mathrm{X}_{1}\right)$ on student's behaviour as citizens of the environment $\left(\mathrm{X}_{4}\right)$ through knowledge of environmental issues $\left(\mathrm{X}_{2}\right)$ and intention to act $\left(\mathrm{X}_{3}\right)$. This shows that environmental sensitivity can influence significantly towards the behaviour of students as citizens of the environment through knowledge of environmental issues and intention to act. Thus, it can be concluded that increasing environmental sensitivity will significantly result in increasing student behaviour as citizens of the environment through knowledge of environmental issues and an intention to act. The higher the environmental sensitivity will be followed by increasing student behaviour as citizens of the environment through knowledge of environmental issues and intention to act. The environmental sensitivity of a student influences the behaviour of students as citizens on the environment through knowledge of environmental issues and the intention to act. The ninth hypothesis proves that environmental sensitivity has a significant influence on increasing knowledge of environmental issues and the intention to act. A student who has high environmental sensitivity and has knowledge of environmental issues will make the student wants to act high in treating the environment which the student will eventually behave wisely as citizens of their environment. If each of the variables is able to significantly influence the behaviour of students as citizens of the environment, the possibility is caused by students who have high environmental sensitivity, of course also have knowledge of environmental issues as well as the high intention to behave as citizens of the environment. It can apply otherwise, students who have high knowledge of environmental issues naturally must have high environmental sensitivity or the intention to act to behave as a citizen of the environment. Environmental sensitivity, knowledge of environmental issues and the intention to act can be a factor for students to behave as citizens of their environment. Students will well behave as citizens towards the environment. In addition, self-sensitivity will be formed within the environment, knowledge of environmental issues and the high intention to act. Students who only have environmental sensitivity or knowledge of environmental issues or only have the intention to act alone can still form good behaviour as citizens of their environment. The ninth hypothesis test of environmental sensitivity, knowledge of environmental issues and the intention to act are able to influence together and not significantly to the behaviour of students as citizens of environment. This research proves the results from Hsu and Roth's research in Hsu (2010) which states there is significant relationship between environmental sensitivity, knowledge of environmental issues with the intention to act. This is also in accordance with the results of research conducted by Cheng and $\mathrm{Wu}$ (2014) concluding that knowledge of environmental issue, intention to act and environmental sensitivity together influence student's behaviour as citizens of the environment. Based on the Hungerford and Volk models (2013) that explain that environmental sensitivity is one of the variables that includes entry-level variables as a prerequisite, or at least the variables to improve one in making decision when going to take an action on the environment, so that one behaves as citizens of their environment. His research explains that environmental sensitivity is an empathy perspective on the environment, which has been considered as one of the variables which contribute to citizenship behaviour towards the environment; close relationship between environmental sensitivity and the development of pro-environment behaviour has been investigated for its relevance. 


\section{CONCLUSION}

Based on the results of the hypothesis above, it can be concluded that:

1. The environmental sensitivity directly influences the knowledge of environmental issues.

2. The environmental sensitivity directly influences the intention to act.

3. The environmental sensitivity directly influences student behaviour as citizens to the environment.

4. The knowledge of environmental issues directly influences the intention to act.

5. The knowledge of environmental issues directly influences student behaviour as citizens to the environment.

6. The intention to act directly influences student behaviour as citizens to the environment.

7. The environmental sensitivity indirectly influences the intention to act through the knowledge of environmental issues.

8. The knowledge of environmental issues indirectly influences the student behaviour as citizens to the environment through the intention to act.

9. The environmental sensitivity to the student behaviour as citizens to the environment indirectly influences the knowledge of environmental issues and the intention to act.

The conclusion is that environmental sensitivity, knowledge of environmental issues, and the intention to act can directly or indirectly influence the student behaviour as citizens to the environment. Each variable is able to be a significant mediator for the other variables.

\section{REFERENCES}

Azjen, I.N., Joyce, S., Seikh, \& N. G. Cote. (2011). Knowledge and the Prediction of Behavior: The Role of Information Accuracy in the Theory of Planned Behavior. Basic and Applied Social Psycology. Vol. 33. 101-117.

Chawla, L. (2016). Significant Life Experiences Revisited: A Review of Research on Sources of Environmental Sensitivity. The Journal of Environmental Education. Vol. 29:3. 11-21.

Chen, L. (2013). A Study of Green Purchase Intention Comparing with Collectivistic (Chinese) and Individualistic (American) Consumers in Shanghai. China. Information Management and Business Review.Vol. 5.No. 7. pp. 342-346,

Cheng, T.M., Wu, H.C., \& Huang, L.M. (2013). The influence of place attachment on the relation-ship between destination attractiveness and environmentally responsible behavior for island tourism in Penghu, Taiwan. Journal of Sustainable Tourism. Vol. 21(8). 1166-1187.

Cheng, T-M., \& Wu, H.C. (2014). How do environmental knowledge, environmental sensitivity, and place attachment affect environmentally responsible behavior? An integrated approach for sustainable island tourism; Journal of Sustainable Tourism.

Colquit, A. J., Lepine, A.J., \& Wesson, J.M. (2011). Organizational Behavior Improving Performance and Commitment in the Workplace. New York: McGraw-Hill. Edisi dua. p.42.

Hsu, S-J. (2010). The Effects of an Environmental Education Program on Responsible Environmental Behavior and Associated Environmental Literacy Variables in Taiwanese College Students. The Journal of Environmental Education. Vol 35:2. 37-48.

Huang, P.S., \& Shih, L.H. (2009). Effective environmental management through environmental knowl-edge management. International Journal of Environmental Science \& Technology. Vol 6(1). 3550.

Hungerford, H.R. \& Volk, T.L. (2013). Changing Learner Behavior Through Environmental Education. The Journal of Environmental Educatio.Vol 21:3. 8-21.

Iskandar, J. (2009). Ekologi Manusia dan Pembangunan Berkelanjutan. Bandung: Program Study Megister Ilmu Lingkungan Universitas Padjadjaran.

Pan, S-L.; Chou, Ju; M., A. M.; Huang, W-S.; \& Lin, M-C. (2018). Whill the Future Be Green? The Environmental Behavioral Intentions of University Tourism Students. Journal Sustainability. Vol 10-634.

Pratama, R.K.O. (2013). Pengaruh Pendidikan Kesehatan Terhadap Perubahan Pengetahuan, Sikap dan Perilaku Tentang Kebiasaan Hidup Bersih dan Sehat Siswa SDN. Fakultas Ilmu Kesehatan Universitas Muhammadiyah Surakarta.

Priadi, A.; Fatria. E.; Nadiroh, S.D., dan Oktaviani, A. (2018). Environmental citizenship behavior (the effect of environmental sensitivity, knowledge of ecology, personal investment in environmental issue, locus of control towards students' environmental citizenship behavior). E3S Web of Conferences. Vol 74, ICSoLCA.

Putrawan, M. I. (2014). Konsep-konsep Dasar Ekologi dalam Berbagai Aktivitas Lingkungan. Bandung. Alfabeta. p.68-70.

Townsend, C. (2000). The effects of environmental education on the behavior of divers: A case study from the British Virgin Islands (Unpublished master's thesis). The University of Greenwich. London.

Widiyanto, A.F.; Yuniarno, S. \& Kuswanto. (2015). Polusi Air Tanah Akibat Limbah Industri dan Limbah Rumah Tangga. Jurnal Kesehatan Masyarakat Universitas Jenderal Soedirman. Vol.2. 246-254.

Yusof, J.M.; G.K.B. Singh; \& R.A. Razak. (2013). Purchase Intention of Environment-Friendly Automobile”. Procedia Social and Behavioral Science. Vol.85. 400-410.. 